\title{
DEVELOPING ENGLISH ELECTRONIC MODULE USING JOB ACCESS WITH SPEECH (JAWS) AS SCREEN READER TO EMPOWER LEARNING AUTONOMY OF STUDENTS WITH SPECIAL NEED
}

\author{
Sri Wiyanah, S.Pd., M.Hum. \\ wiyana.pbiupy@gmail.com \\ English Education Study Program \\ Universitas PGRI Yogyakarta
}

\begin{abstract}
The research and development produces interesting, interactive, and suitable learning resources for students with special need, i.e., students with visually impaired in order to develop students' empowerment. Development of electronic module proposes electronic resources by applying Job Access with Speech (JAWS) as screen reader on the computer to accommodate some obstacles of visually impaired students in learning English. Therefore, it is helpful for them to learn better by maximizing their potential and their restrictiveness to become creative and autonomous learners.

Qualitative research was applied in this research. Data was collected from observation, interview, questionnaire and note taking in a kind of daily agenda. Data was described qualitatively. The data finding then analyzed in order to produce a suitable electronic module. The research model is Research and Development that was proposed by Borg and Gall. There are seven stages that was done, i.e. (1) Research and Information Collection (2) Planning (3) Develop Preliminary form of Product (4) Preliminary Field Testing (5) Main Product Revision (6) Main Field Testing (7) Operational Product Revision. The product of English electronic was validated by English teacher or material expert, media expert and 2 visually impaired students from different level. Instruments' assessments include module organization, material, evaluation and readability, display and also programming.

The findings produced a very good quality module based on teacher, students, material and media expert. Form the material, the average score was 4, 2 and the percentage was $84 \%$. From media point of view, the average score was 3,7 and the percentage was 76. It also got good responses from the visually impaired students. They enjoyed learning with the module. They feel happy and free in learning. Moreover, the empowerment in learning could be reached. English electronic module was suitable and feasible for the visually impaired students in learning English.
\end{abstract}


Ahmad Dahlan Journal of English Studies (ADJES)

Vol. 3, Issue 1, March 2016

Keywords: English Electronic Module, Learning English, JAWS, Empowerment, Students with Special Need

\section{Introduction}

New perspective in education proposes an autonomous in learning process in order to shape creative and autonomous individual learner. In the teaching learning process, children are provided some tools or electronic media as one of medium to facilitate students with special needs in learning. Development of knowledge and technology today has given positive contribution in using many kinds of modern technology. That gives great influence for the visually impaired. It may motivate students to learn, develop their creativity, thought pattern, and innovation. Therefore, their restrictiveness in seeing does not become an obstacle anymore to keep learning and does not leave behind in following the era and sophisticated technology.

This research responds the phenomenon of students with special need, especially the visually impaired students from teaching approach and learning materials as learning resources. It uses electronic media as a learning tool by designing interesting, flexible, interactive and suitable module that is responsive to their restrictiveness, variety and ability of students with special need. Nevertheless, they use Braille as a tool in reading and writing. But it needs more time and space. Therefore, it is sometimes not effective in learning, especially when they need to read and look for broader information by using Braille reading sources. That is way, it is useful to design learning material resources that is easy to learn and use by using informational technology. It can also be accessed individually and group to improve their thought pattern creatively. It is one of innovation to improve the students with special need's autonomy to be self confident, autonomous, in socializing and competing with other normal students.

That is why; it needs to design an electronic learning resource that is suitable for them. Now, students with visually impaired are JAWS (Job Access with Speech), as a screen reader that is kind of software as learning media. But, they do not have learning sources for that media. Moreover, they do not maximize in using JAWS in class situation because there is no learning material or resources that can be accessed to support their activity. Electronic module is a modern learning material that uses technology facilities in order to attract students' attention in developing themselves based on their characteristics, ability, background, physical and psychological that is diversity. This research develops electronic module that is using JAWS as a screen reader as a media. The module adopts and develops e-book that is available at school that employ new curriculum.

Based on the background, there are some problems that can be identified, i.e., student with special need, visually impaired has obstacle in learning English due to conventional learning tools that needs time and space to be used. Book provided by government is not suitable, responsive and interesting for them to be learnt, because the government does not consider the students need and ability. Teaching Model is done the same as the normal students with the same curriculum. The development of knowledge and technology demands student with special need to 
use it in order to get improvement in their learning achievement. They used JAWS as learning media, but there is no learning material to support their activity.

Based on the identification of the problem, it can be formulated that (1) Is the English electronic module feasible for the students with special need to learn?

(2) Does the learner autonomy improve by using this learning material development?

The purposes of this research are to produce a feasible English electronic module for students with special need to learn using JAWS and improve learner autonomy by using this learning material development.

\section{Literature Review/Related Works Electronic Module}

Module is an organization of material that focuses on education function. Wijaya, Cece (1992) states that the term of electronic module is a combination the term of module in learning material in the form of electronic learning material or e-book. Electronic module is a presentation of a standalone learning material that is arranged systematically into small learning unit to reach the certain learning purposes, presented in the form of electronic.

Based on the definition of module and electronic module above, it seems that there is no principal difference between conventional module and electronic module. The different between them is only on the presentation format physically. There is no different about module components. Generally, electronic module adapts some components in the printed out module.(Gunadharma, Ananda, 2011 in Sudiartayasa Nyoman dkk., 2014:21)

Characteristics of print out module can be adapted in the electronic module. The following characteristics are electronic module characteristics that are adapted from print out module as what Sitepu (2006:109) stated, i.e.:

1. Self-Instruction means module is arranged as well as possible in order learner can understand without any help from others. There is information about references that support the learning materials intention.

2. Self-contained means that all materials from a unit of competence or sub competence that are learnt are in the one module in whole.

3. Stand alone means that developed module cannot depend on other media and used together with another media.

4. Adaptive means module should has high adaptive power toward development of knowledge and technology, up to date, and flexible.

5. User friendly means module is easy to be used, operated, the instruction is easy to be understood and responded by the learner.

\section{Job Access with Speech (JAWS)}

The visually impaired student has restrictiveness in seeing, so the learning process focuses on his senses, i.e., touching and hearing. Media that used is tactual and has a voice. For example Braille writing, emerge picture and real things, whereas voice media like tape recorder Screen Reader such as JAWS, Thunder, that can change the text in the monitor screen becomes voice. (Hermawati, Kuswari, 
2011:141). Jobs Acces with Speech (JAWS) is a screen reader that is a part of software that is useful for visually impaired students in using computer as learning media JAWS cannot be used to read table, number and picture (Supalo, 2007).

\section{Students with Special Need (SSN)}

Students who in the process of growing or developing significantly undergo divergence or deviation (physics, mental intelligence, social, and emotional) compare with the other students in their same level of age need special educational service. It means that students who get certain deviation need special education needs (Depdiknas, 2004).

\section{Autonomy}

Current perspectives in education emphasize on the achievement of an autonomy and empowerment of the learners in their learning. Learners need to learn because they need to be self-fulfilled individually and socially. In order to become self-fulfillment they should become empowered. Autonomy is as the ability to take charge of one's own learning. In other words, it is the capacity to control one's own learning. It is seen as a natural product of the practice of self-directed learning, or learning in which the objectives, progress and evaluations of learning are determined by the learners themselves (Benson, 2001:8).

\section{Related Works}

Relevant findings that were done and related to the research i.e.: Dewi Perwita Sari, entitled Pengembangan Modul Kimia Menggunakan Media Screen Reader Job Access with Speech (JAWS) Materi Pokok Sistem Periodek Unsur $S M A / M A$ Inklusi Kelas $X$. This research produce chemistry module..Then Sudiartaya, Nyoman Adiputra etc.., entitled Pengembangan E-Modul Pada Materi "Melakukan Instalasi Sistem Operasi Jaringan berbasis GUI dan Text Untuk siswa Kelas X Teknik Komputer dan jaringan SMK Negeri 3 Singaraja that produced electronic module for computer technique students. This research produced English electronic module using Job Access with Speech (JAWS) as screen reader for students with special need of visually impaired to empower their learning autonomy.

\section{Material \& Methodology}

This research method used qualitative method.In qualitative research, all things and phenomenon are observed and noted. The location of research was at YaKetunis or Yayasan Kesejahteraan Tuna Netra Islam. It is located on di Parangtritis street no. 46 Mantrijeron Umbulharo Yogyakarta. The subjects of research were 2 visually impaired students who stayed in Yaketunis and studied in inclusive school of Sewon senior high school. The research is Research and Development ( $R$ \&D) that is a process or steps to develop a new product or complete something available and also validate educational product that can be responsible (Borg and Gall (1989:782).

Borg and Gall (1989: 783-795) states that there are seven stages in R and D, i.e (1) Research and Information Collection (2) Planning (3) Develop Preliminary form 
of Product (4) Preliminary Field Testing (5) Main Product Revision (6) Main Field Testing (7) Operational Product Revision.

Data was collected from observation, interview, questionnaire and note taking in a kind of daily agenda. Data was described qualitatively. The data finding then analyzed in order to produce a suitable electronic module. Data is in form of qualitative and quantitative that is derived from questionnaire. Quantitative data is in the form of numbers, i.e.:5 (very good/feasible), 4 (good), 3 (good enough), 2 (bad) and 1 (worst). Qualitative data is derived from person in charge and students based on their suggestions and critics. The product of English electronic was validated by English teacher or material expert, media expert and 2 visually impaired students from different level. Instruments' assessment include module organization, material, evaluation and readability, display and programming.

Data collection instrument is validation questionnaire. Questionnaire consists of two such as checklist (quantitative data) suggestions and critics sheets (qualitative data). Every item on the checklist is given score by using Linkert scale to know the value of module electronic validity. Data analysis technique used to analyze quantitative data from the subject of validation and subject experiment is percentage descriptive technique by changing quantitative data becomes percentage. The following data is interpreted by qualitative sentences. (Sudjana, 2005 in Astiwi, 2012).

\section{Results and Discussion Results}

The finding was an English electronic module by applying Job Access with Speech (JAWS) as screen reader and to know the feasibility of the module in order to empower the students' autonomy in learning. The developed English electronic module was feasible to be used based on material expert validation, media expert, experiment and responses from the students and teacher.

Development model in this research was done in the following explanation.

\section{a. Research and Information collection}

This stage started by observeing of content standard. It was then done by designing a competency standard mapping and content competency. Observation also was done in the English curriculum 2013. The curriculum has a purposes to set up attitude, knowledge, and communication skill of students through learning experience in the form of active communication, both receptive and productive skills. This module was designed in order to implement the curriculum 2013 and help students in reaching four skills in content competency. The materials that were developed in the module i.e., narrative, recount, report and analytical exposition for senior high school students of visually impaired.

\section{b. Planning}

This stage was about designing research instrument items that would become a electronic media evaluation criteria. It was developed into research instruments. The research instruments were validation sheet, observation sheet, and interview guidance. 


\section{c. Preliminary product development}

The stages was done by designing product of English electronic module by using Job Access with Speech (JAWS) as screen reader for visually impaired students. The steps were such as 1 ) design mapping concept for every base competence that involved four skills such as listening, speaking, reading and writing. 2) mapping concept then used as a standard to design activities in every skill. 3) Activities were designed based on observation and syllabus guidance of 2013 curriculum. 4) After designing materials, media was given an audiovideo to support the materials learned by students.

\section{d. Preliminary Field Testing}

This module validation was done in order to know the feasibility from the material and media expert. Module validation was done by 1) material expert that has competency in teaching English and their teacher at school. 2) Media expert from IT person and 3) user module i.e., visually impaired students. The product of media that was validated then revised based on the suggestion and opinion of the expert in the process of validation. After the media was revised, then experiment was done to know students responses toward the product. The experiment was done in using the module for learning English. Students were interviewed to get responses, suggestions and comments in using the module. The module needed to be revised in order to produce feasible English electronic module.

The first English electronic module product was validated by material and media expert. The score was 3, 79. It was good. To get better result there was revision and validation for the second. The score was 4,10 . It was good. So, the module has fulfilled the standard. The score of validation rose up and the module has been developed with better quality. The product enumeration by material expert based on the average score was presented in the following diagram.

\section{Diagram of Validation Result from Material Expert}

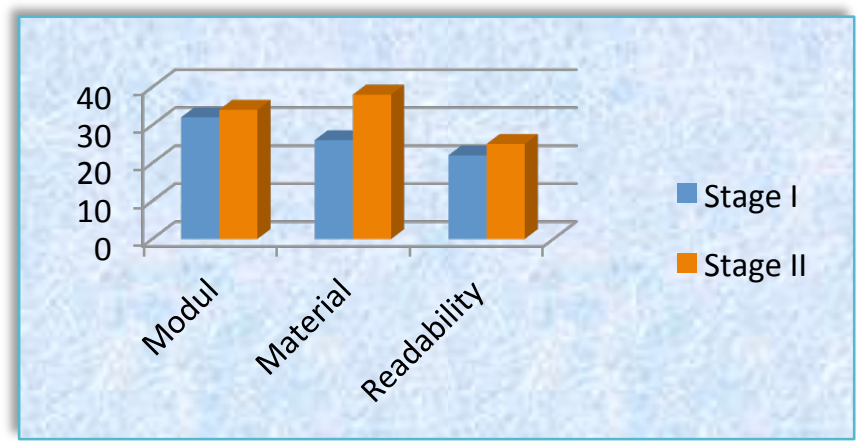

Diagram 1. Validation of Material Expert

Media expert validated it twice. It was because the first validation, the score average 2,8 . It was enough categories. So it has not fulfilled the standard of try out. Then, based on the suggestions and comments from media and material expert, the media need to be revised and validated. In the second stage, 
the average score showed 3, 7. It was in good category. Based on the result above, the media had been feasible to be tried out. The product enumeration by media expert based on the average score was presented in the following diagram.

\section{Diagram of Validation Result From Media Expert}

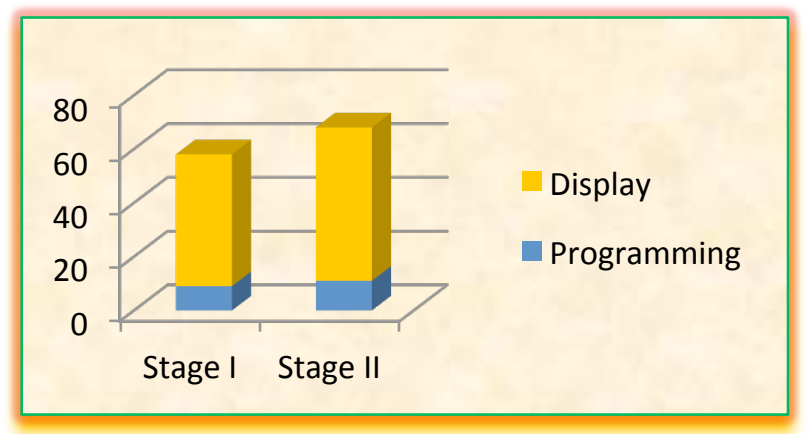

Diagram 2. Validation Media Expert

\section{Discussion}

The Research and Development produced English electronic module by using Job Access With Speech (JAWS) as screen reader for visually impaired students to empower autonomous learning. The validation of material and media were validated by some experts in their filed of knowlegde. The validation did twice for material and media. The last validation produced better result. Thus, English electronic module as the product of the research was feasible and suitable for visually impaired students.

Some important things that should be revised from the material validation i.e.: 1) the consistency of the content list and the module content, 2) the consistency of generic structure materials from one text to another, 3) there were some mistake in spelling that influence the meaning, 4) missing of punctuation, 5) evaluation technique for reading skill need to be improved, 6) the summative test need to be improved such as the clear instruction, space, the consistency of optional answer.

Whereas, from the media validation, there were some suggestions from the media expert i.e.: 1) the display of module design should be improved in order to be more interesting, 2) the audio need to be revised became more clear and louder, 3) students needed a speaker or headset to make them easier in learning, (4 the students was not able to use and open video using hyperlink. Therefore, the video file should be put in the folder with different file. From all critics and suggestions, the researcher responded all the items in order to get better result product of English electronic module.

The research and development referred to some stages proposed by Borg and Gall (1983: 775). It stated that there are ten stages in the research and development. In this research, researcher simplified the stages became seven 
stages. There were some factors that consider in simplifying the stages, i.e.: limited time and the cost. If the research did ten stages, it would need long time and process that could not be reached in this term. Therefore, making the stages simpler and shorter would be better without influence the effectiveness of the process and result. There would spend much cost to conduct the research up to ten stages. Because of that, stages simplifying will save cost.

The visually impaired students had restrictiveness in English learning especially related to learning tools need much time and space that is still out of date. The book from the government was not feasible, effective, interesting and responsive for visually impaired students. It did not determine the need variety and students' ability and condition. It was not able to accommodate the students with visually impaired, where they used their sense of hearing, whereas in the electronic book there were many pictures that could not be seen and learn. Thus, students need to be provided module based on the students condition that have visually impaired. Teaching model was conducted with the same treatment both normal and students with visually impaired by using the same curriculum. Science and technology development demanded student with visually impaired to use it in order to improve their ability in learning English. The students with visually impaired used JAWS as a media to learn English, but there was no learning resources to be used. Thus, electronic module could be one of learning sources to complete another electronic media like JAWS as screen reader.

The product of the research was English electronic module for the first and second grade of senior high school students who are visually impaired. The first English electronic module product was validated by material and media expert. To get better result there was revision and validation for the second. So, the module has fulfilled the standard. The score of validation rose up and the module has been developed with better quality. Media expert validated it twice. Then, based on the suggestions and comments from media and material expert, the media need to be revised and validated.. Based on the result above, the media had been feasible to be tried out.

Autonomy means students can access some information and learn based on their rules and initiative. Moreover, autonomy was same with learning based technology that will help students in learning. Individual access means will be automatically refers to autonomy, because access center has opened user technology enthusiasm. Learning by accessing tended to have the same meaning with learning based technology.

\section{Conclusion}

Based on the result and discussion above, there were some conclusions that could be derived:

1. The product that produced and developed using JAWS as screen reader has some materials i.e., narrative, recount for grade $X$ and report, analytical exposition for grade XI. The characteristics were:

a. Development Characteristics

Developing English Electronic Module Using Job Access With Speech (Jaws) as Screen

Reader to Empower Learning Autonomy of Students with Special Need 
Electronic module was developed by emphasizing the four skills concept in learning English such as listening, speaking, reading dan writing. This module was especially made for visually impaired students. Using JAWS as screen reader that made all the texts could be read and changed in the form of voice. So, it will accomodate the visually impaired students in using their senses of hearing. The audio and story film provided to support the material. The module was developed with Borg and Gall model applying seven stages.

b. Product Characteristics

English electronic module consisted of 4 sub materials, i.e., narrative, recount report, and analytical exposition. Module was equipped formative test in the last part of activities, leaning indicator, earning purposes, mapping concept, material mastery, and various activities of four skills, summary, glossaries, answer key, reflection, and references.

2. English electronic module quality was very good with average 4, 2 and the percentage was $84 \%$. The responses of 2 visually impaired students toward module were very good.

3. Therefore, English electronic module was feasible to be used as an alternative of learning resources to be autonomous. There were some restrictiveness in developing the module. There were only 2 visually impaired students, 1 material expert, 1 media expert and teacher of the visually impaired student. The disseminating and implementation were not conducted, because it needed a broader experiment and deeper research like case study, experiment or class action research. This module can be tried out in the students learning process at school. After it had been tried out and produced a feasible validation result, then it could be disseminated and used by English teacher and students of visually impaired in learning. Further research needed to be conducted in order to improve students with visually impaired in learning others things and knowledge.

\section{REFERENCES}

Astiwi, Frilia Windy. 2012. Pengembangan Modul Pembelajaran Elektronik Berbasis Multimedia Pada Mata Pelajaran Biologi Materi Sistem Peredaran Darah Pada Manusia untuk Siswa SMP. Skripsi tidak diterbitkan. Malang: Universitas Negeri Malang.

Benson, P. 2001. Teaching and Researching Autonomy in Language Learning. London: Longman.

Borg, W.R. \& Gall, M.D. Gall. (1989). Educational Research: An Introduction, Fifth Edition. New York: Longman.

Dewi Perwita Sari. 2013. Pengembangan Modul Kimia Menggunakan Media Screen Reader Job Access with Speech (JAWS) Materi Pokok Sistem Periodek Unsur $S M A / M A$ Inklusi Kelas X.Skripsi. tidak diterbitkan. Univeritas Islam Negeri Sunan Kalijaga. (online)(http://digilib.uinsuka.ac.id/7232/1/BAB\%20I,\%20V,\%20DAFTAR\%20PUSTAKA.pdf, accessed on 28 March 2015) 
Ahmad Dahlan Journal of English Studies (ADJES)

Vol. 3, Issue 1, March 2016

Gunadharma, Ananda.2011. Pengembangan Modul Elektronik Sebagai Sumber Belajar Untuk Mata Kuliah Multimedia Design. Skripsi (tidak diterbitkan). Jurusan Teknologi Pendidikan Fakultas Ilmu Pendidikan, Universitas NegeriJakarta.(online).

(http://www.slideshare.net/anandagunadharma/pengembangan-modulelektronik-sebagai-sumber-belajar-untuk-mata-kuliah-multimedia-designananda- gunadharma-1215051060., accessed onl 20 March 2015)

Hermawati, Kuswari. 2011. E-learning untuk Siswa Berkebutuhan Khusus. Yogyakarta: Fakultas Matematika dan Ilmu Pengetahuan UNY. Prosiding. ISBN. 978-979-16353-6-3

Dirtektorat Pendidikan Luar Biasa.2004. Mengenal Pendidikan Terpadu. Depdiknas Sitepu, B.P., 2006. Penyusunan Buku Pelajaran, Jakarta: Verbum Publisginh.

Sudiartaya, Nyoman Adiputra dkk., 2014. Pengembangan E-Modul Pada Materi"Melakukan Instalasi Sistem Operasi Jaringan berbasis GUI dan Text Untuk siswa Kelas X Teknik Komputer dan Jaringan SMK Negeri 3 Singaraja.Vol.3 No.1

Supalo, Carry, E. Moulk, Thomas, et al. 2007.Talking Tools to Assist Student Who Blind in Laborratoy Course. Science for Dissability. Vol 12:26-30

Wijaya, Cece. 1992. Upaya Pembaharuan dalam Pendidikan dan Pengajaran. Bandung: Remaja.

Developing English Electronic Module Using Job Access With Speech (Jaws) as Screen Reader to Empower Learning Autonomy of Students with Special Need 